\title{
Urban Heat Island Effects on Megacities in Desert Environments Using Spatial Network Analysis and Remote Sensing Data: A Case Study from Western Saudi Arabia
}

\author{
Mady Mohamed ${ }^{1,2} \mathbb{D}$, Abdullah Othman ${ }^{3,4, *}$, Abotalib Z. Abotalib ${ }^{5,6}{ }^{\mathbb{D}}$ and Abdulrahman Majrashi ${ }^{7}$ \\ 1 Architecture Department, Effat University, Jeddah 21478, Saudi Arabia; momohamed@effatuniversity.edu.sa \\ 2 Architecture Department, Faculty of Engineering, Zagazig University, Zagazig 44519, Egypt \\ 3 Natural Hazards and Geoinformatics Research Unit, Department of Environmental and Health Research, \\ Umm Al-Qura University, Makkah 24381, Saudi Arabia \\ 4 Department of Environmental Engineering, Umm Al-Qura University, Makkah 24381, Saudi Arabia \\ 5 Division of Geological Applications and Mineral Resources, National Authority of Remote Sensing and Space \\ Sciences, Cairo 11843, Egypt; afarag@usc.edu \\ 6 Viterbi School of Engineering, University of Southern California, Los Angeles, CA 90089, USA \\ 7 Department of Islamic Architecture, Umm Al-Qura University, Makkah 24381, Saudi Arabia; \\ aamajrashi@uqu.edu.sa \\ * Correspondence: agothman@uqu.edu.sa; Tel.: +966-555-88-1721
}

\section{check for} updates

Citation: Mohamed, M.; Othman, A.; Abotalib, A.Z.; Majrashi, A. Urban Heat Island Effects on Megacities in Desert Environments Using Spatial Network Analysis and Remote Sensing Data: A Case Study from Western Saudi Arabia. Remote Sens. 2021, 13, 1941. https://doi.org/ $10.3390 /$ rs13101941

Academic Editors: Ahmed Mustafa and Andreas Rienow

Received: 4 March 2021

Accepted: 12 May 2021

Published: 16 May 2021

Publisher's Note: MDPI stays neutral with regard to jurisdictional claims in published maps and institutional affiliations.

Copyright: (C) 2021 by the authors Licensee MDPI, Basel, Switzerland. This article is an open access article distributed under the terms and conditions of the Creative Commons Attribution (CC BY) license (https:// creativecommons.org/licenses/by/ $4.0 /)$.
Abstract: Contemporary cities continue to face significant geoenvironmental challenges due to constant rapid urbanization. Furthermore, the governments of cities worldwide are considering the green cities approach to convert their cities' weaknesses into opportunities. The 2030 Saudi vision supports smart growth concepts, with a vision of speeding up economic growth while ensuring that natural assets strengthen the country's foundations. The urban heat island (UHI) effect is a threatening phenomenon that increases the required cooling loads and negatively affects urban communities and the quality of life, especially in arid environments. This study integrates remote sensing and spatial network analysis to investigate the UHI using the distribution of land surface temperatures (LST) extracted from satellite data during both winter and summer seasons in Makkah city. We investigated and compared the UHIs in two districts, Al-Sharashef and AlEskan, representing the organic and deformed iron-grid with fragmented paralleled street networks, respectively. The spatial analysis of different LST maps, which were derived from Landsat-8 images revealed significant differences between the two case studies. The mean temperature for the AlEskan district was $1-1.5^{\circ} \mathrm{C}$ higher than that of the Al-Sharshaf district. This difference can be attributed to the different urban fabrics between the two districts. Moreover, the zones that are currently under construction show relatively higher LST compared to residential zones. The research revealed that the organic/compact urban fabric is better than the deformed iron-grid urban fabric in mitigating the UHI. However, these results are specific to the test site; however, they emphasize the role of integration of remote sensing and spatial network analysis in urban planning. In light of these findings, we recommend integrating remote sensing-based LST analysis with spatial analysis of urban fabrics to better understand the causal effects of UHI, especially in cities located in desert environments. This can help mitigate the impact of projected global warming and contribute to improving the quality of urban life.

Keywords: urban heat island (UHI); land use; geoenvironment; sustainability; land surface temperature (LST); urban morphology and geometry; geoinformatics

\section{Introduction}

More than half of the world's population lives in cities; by 2050, the proportion of people living in urban areas is expected to increase up to $70 \%$ [1-3], forming large communities that will create challenges and opportunities for environmental developers and designers in reaching the various goals of sustainable cities. Cities and their activities 
are a significant reason for producing $60 \%$ of the world's carbon dioxide and greenhouse gas emissions that contribute directly to the global warming problem. Climate change with the increase in temperature is another challenge for cities to reduce their impacts and develop an adjustment to these changing conditions [4-6]. Thus, the increasing demand for sustainability is pushing societies worldwide toward rapid changes in policies, laws, and regulations regarding urban design and processes to encourage more sustainable designs [7-9].

An urban heat island (UHI) is "an urban area or metropolitan area that is significantly warmer than its surrounding rural areas due to human activities" [10-13]. The temperature difference is usually higher at night than during the day and is more apparent when winds are weak. Mitigation of the UHI's effects can be achieved through several actions [14-16], such as (1) reducing the exposed surface area of materials (mainly asphalt and concrete with low albedo and high admittance); (2) increasing vegetation and porous surfaces, which maximizes shade and evapotranspiration; (3) reducing tall buildings and narrow streets that modify overall wind speeds; and (4) reducing the concentration of heat-generating activities, such as fuel combustion (including cars), the use of heating, ventilation, air conditioning (HVAC) systems, and other anthropogenic processes.

UHIs are affected by urban land cover (i.e., the radiation properties of the surfaces and the anthropogenic heat release, e.g., by a house fire, traffic, and industry), the neighborhood building configuration (e.g., the building geometry and the thermal properties of the building fabric), and adjacent heat sources and sinks [17-19].

There are few classifications for heat islands. Arrau and Pena [20] classified heat islands into five types, namely, heat island, urban heat island effect, (3) surface urban heat island, micro-urban heat islands, and urban heat sink. The urban heat sink refers to cities colder than their surrounding countryside.

Additionally, the Environmental Protection Agency [21] classified the UHIs into two types: surface UHIs and atmospheric UHIs. The essential characteristics of each type of UHI is summarized in Table 1.

Table 1. Basic characteristics of surface and atmospheric urban heat islands (UHIs). Reprinted from ref. [21].

\begin{tabular}{|c|c|c|}
\hline Feature & Surface UHI & Atmospheric UHI \\
\hline Temporal Development & $\begin{array}{l}\text { - } \quad \text { Present at all times of the day and night } \\
\text { Most intense during the day and in the } \\
\text { summer }\end{array}$ & $\begin{array}{l}\text { - May be small or non-existent during the } \\
\text { day } \\
\text { - Most intense at night or predawn and in } \\
\text { the winter }\end{array}$ \\
\hline $\begin{array}{l}\text { Peak Intensity (Most intense UHI } \\
\text { conditions) }\end{array}$ & $\begin{array}{l}\text { More spatial and temporal variation: } \\
\text { Day: } 18 \text { to } 27^{\circ} \mathrm{F}\left(10 \text { to } 15^{\circ} \mathrm{C}\right) \\
\text { Night: } 9 \text { to } 18^{\circ} \mathrm{F}\left(5 \text { to } 10^{\circ} \mathrm{C}\right)\end{array}$ & $\begin{array}{l}\text { Less variation: } \\
\text { Day: }-1.8 \text { to } 5.4^{\circ} \mathrm{F}\left(-1 \text { to } 3^{\circ} \mathrm{C}\right) \\
\text { Night: } 12.6 \text { to } 21.6^{\circ} \mathrm{F}\left(7 \text { to } 12^{\circ} \mathrm{C}\right)\end{array}$ \\
\hline Typical Identification Method & $\begin{array}{l}\text { Indirect measurement: } \\
\text { - } \quad \text { Remote sensing }\end{array}$ & $\begin{array}{l}\text { Direct measurement: } \\
\text { - } \quad \text { Fixed weather stations } \\
\text { - } \quad \text { Mobile traverses }\end{array}$ \\
\hline Typical Depiction & - $\quad$ Thermal image & $\begin{array}{ll}\text { - } & \text { Isotherm map } \\
\text { - } & \text { Temperature graph }\end{array}$ \\
\hline
\end{tabular}

UHIs can be exacerbated by the inappropriate design of the urban fabric, inappropriate building and surface materials, a lack of vegetation, and designed urban activities $[10,12,13,17,18,22]$. As a result, UHIs have been a central theme among climatologists, planners, and urbanists and are well documented in several metropolitan areas worldwide [23-31]. Two factors related to the urban fabric significantly affect the UHI; these are the urban morphology and the urban geometry. Urban morphology refers to the study of the urban form that focuses on the formation and transformation of urban structures of cities over time; their spatial patterns at different scales; and physical characteristics to inform appropriate urban interventions [32]. There are several street styles (Figure 1); the 
most common styles are the conventional grid "Gridiron", curvilinear loop pattern, and conventional cul-de-sac patterns [33].

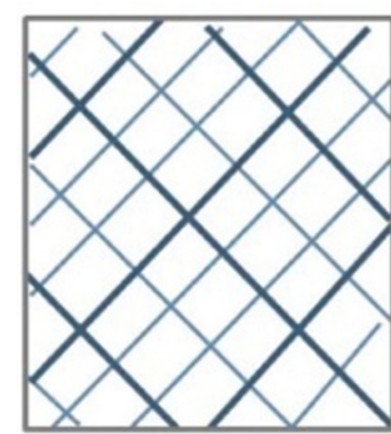

Conventional Grid

Pattern (c 1990)

— Arterial road

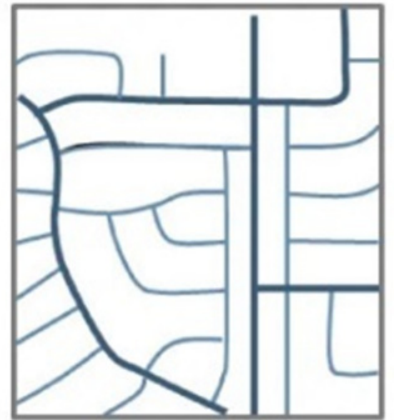

Curvilinear Loop Pattern \& Beginning

of Cul-de-Sacs (1930-1950)

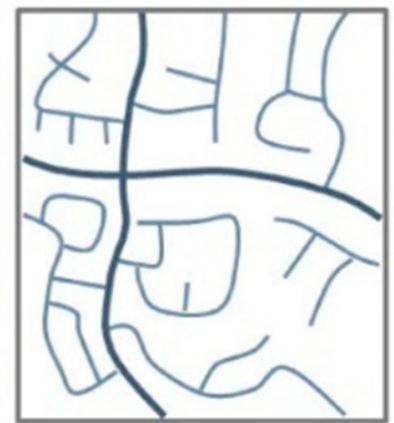

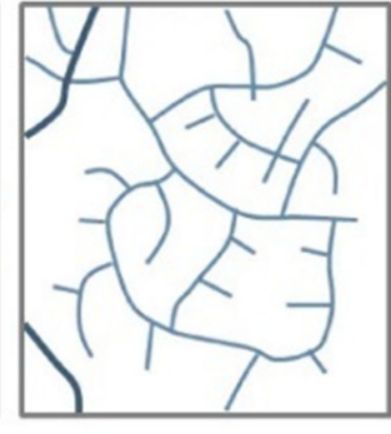

Conventional

Cul-de-Sac

Pattern (since 1950) Local street

Figure 1. Different street types. Reprinted from ref. [33].

The arrangement, coverage, and material properties are the main factors that describe the effect of urban morphology [34]. They can be measured by the building's height, density, height to width ratio, and Sky View Factor (SVF). The building layout can obstruct the wind flow, limit the ventilation within the canopy layer, and increase the air temperature. Building and pavement materials with low albedo levels can also increase the urban heat island UHI [21,35]. Rode et al. [36] studied the impact of the morphological parameters of different types of urban forms on energy demand. The study was conducted on four cities: London, Paris, Berlin, and Istanbul. The results of this study suggested that compact and tall building types have the greatest heat-energy efficiency at the neighborhood scale, while detached housing was found to have the lowest effect. While detached housing systems offer more SVF and allow air circulation and lighting. They added that using a high albedo level in roofs can decrease the energy demand for heating and cooling. Urban geometry is another factor that significantly influences the formation of the urban heat island by limiting the wind flow, increasing the solar absorbing, and increasing the level of long radiation reflected into the atmosphere [37]. The urban geometry refers to the spacing between the city's buildings and most known as the urban canyons [38]. The streets, roads, and pathways surrounded by the city's buildings paved for pedestrians or vehicles create the urban canyons. The urban canyons can be surrounded by tall buildings that shade the streets during the day and by short buildings where the building structure's shading is not extensive [21]. A dense urban center tent allows for smaller canyons surrounded by tall buildings with low albedo levels that absorb and reflect solar radiation. However, tall buildings provide more shading that reduces the surface temperature and air temperature. When the sun reaches the surface, it is reflected and absorbed by the building walls, which increases the energy demand for cooling in the buildings' interior. During the night, urban canyons reduce the cooling process where the buildings obstruct the heat releases from the surface layer. The continued demand for cooling increases the anthropogenic heat production that highly influences the urban heat island. Small dense urban canyons that have a building layout with no consideration for wind direction obstruct the airflow and limit the air circulation throughout the building [39]. The height to width ratio impacts the amount of the radiation absorbed by the buildings, where the longwave radiation is absorbed more by buildings with smaller canyons. Cool pavement is among the tools that reduce the surface temperature and mitigate the urban heat island UHI. Having high albedo pavement within the canyons can increase the urban heat island rather than lower it [40]. Due to the reflective pavement, the radiation is reflected even more by the building's 
walls, which increases the air temperature within the canopy layer. The buildings also absorb it and increase the sensible heat in the urban canyons, especially during the night when the heat cannot escape from the building structure to the atmosphere [35].

Remote sensing applications have been widely used for the assessment of UHI as well as other environmental problems [41] with more than 492 published articles until 2019 that dealt with the application of remote sensing and satellite imagery to extract land surface temperature (LST); report, characterize, assess, and understand driving forces of UHIs; and provide mitigation measures [42]. Remote sensing-based UHI started in the early seventies (1972) using relatively coarse resolution satellite data and low-accuracy (ITOS-1 thermal bands; spatial resolution: $1.1 \mathrm{~km}$ ) [43]. At the beginning of the nineties (1990), Landsat images, with a considerably finer resolution $(60-120 \mathrm{~m})$, became the main tool for mapping UHI around the globe [44]. However, Landsat data are only available during the daytime. With the advent of the Advanced Spaceborne Thermal Emission and Reflection Radiometer (ASTER) data in 2005, mapping UHI became available during the day and night times [45]. Such availability significantly affected the accuracy and quality of the interpretation of UHI distribution and the mechanism of formation.

The integration of remote sensing-based estimations of LST with the spatial distribution of urban fabrics in megacities dominated by hyper-arid condition is poorly examined. In this study, we integrated remote sensing-based LST estimation and spatial network analysis to investigate the effect of urban fabric on the distribution of UHI using two districts in Makkah city, Saudi Arabia, as test sites. This can help us to better understand the causal effects of UHI in megacities in desert environments and thus provides proper mitigation measures to improve the quality of urban life.

Our research aim was fulfilled through the following objectives:

(a) Exploring the climatic conditions and different urban heat island (UHI) types, and revising the definition of UHI in Makkah city;

(b) Extracting LST using different Landsat-8 images for the winter and summer seasons;

(c) Analyzing and comparing the effect of the urban fabric on the LST for two districts in Makkah city.

\section{Research Methodology}

\subsection{Site Description}

Makkah city is among the biggest cities in Saudi Arabia. It occupies the western region of the kingdom (Figure 2A). Makkah is located in a desert valley that occupies an area of about $1200 \mathrm{~km}^{2}$, with an average air temperature of $31^{\circ} \mathrm{C}$, $\mathrm{RH}$ of $46 \%$, average precipitation of $111.8 \mathrm{~mm}$, and mean daily sunshine hours of $9.3 \mathrm{~h} \mathrm{[46].} \mathrm{Makkah} \mathrm{has} \mathrm{a} \mathrm{population} \mathrm{of}$ $1,323,624$ [47].

The investigated area is located in the west-central part of the Pre-Cambrian Arabian Shield. This geological area is mostly composed of igneous, metamorphic, and some sedimentary deposits and rocks. The intrusive diorite, quartz diorite, and tonalite rocks predominate the study area, giving rise to a massive batholith that is called the Kamil suite, which id cut by younger post-tectonic granite intrusions as well as intrusive metagabbro and felsic dikes [48,49] (Figure 2B). The hydrological processes and associated weathering, which have been triggered by the opening of the Red Sea [50], cut deep channels in the PreCambrian rocks and left behind thick alluvium sediments that are mixed with aeolian and talus sediments. The geological structures include faults of northeast to north-northeast trends [51]. 


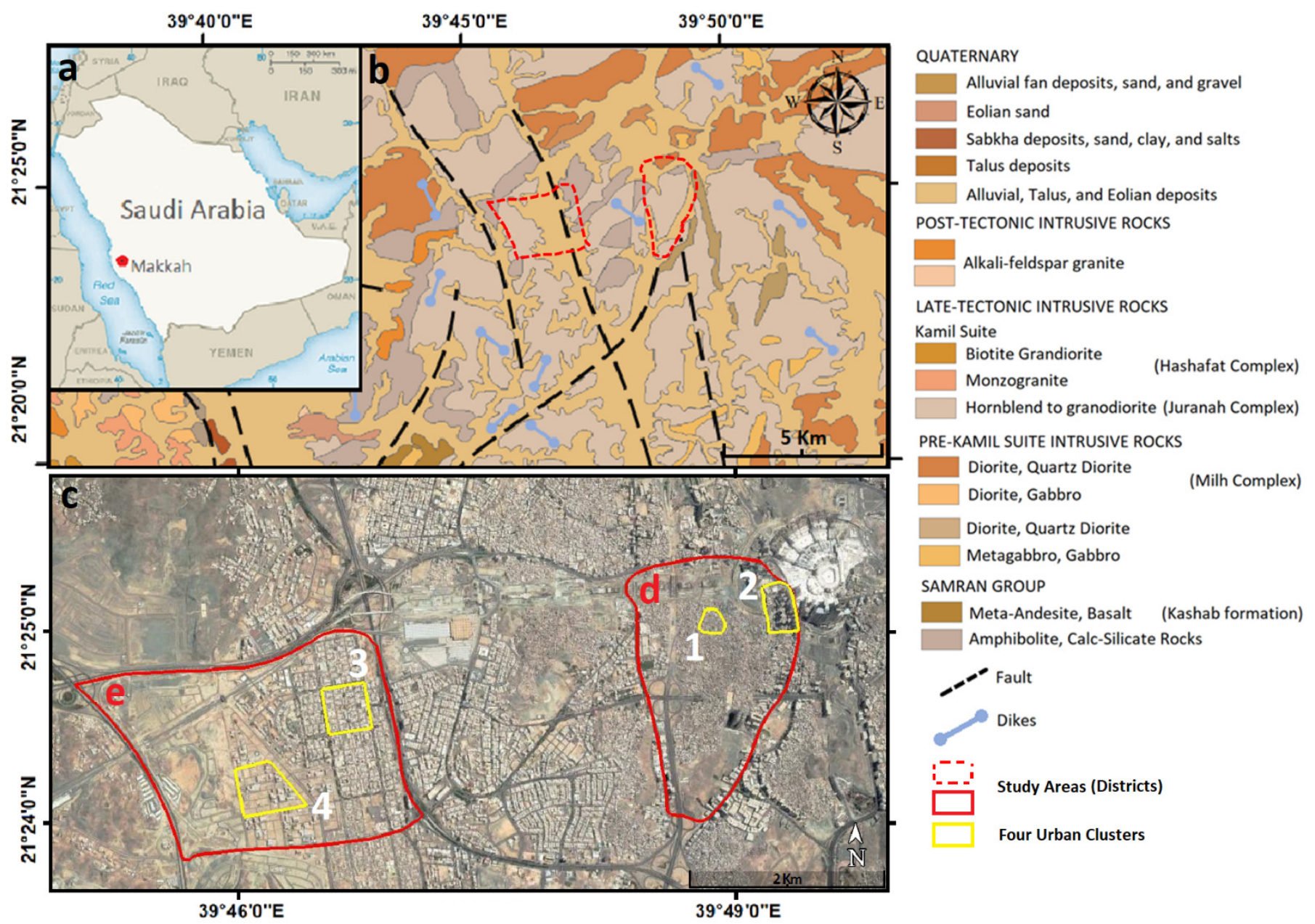

Figure 2. (A) The location of Makkah city; (B) geological map showing the distribution of rocks units in Makkah. Reprinted from ref. [52]; (C) locations of the four clusters inside the two selected districts (D-AlSharashef; E-AlEskan).

Four clusters (the cluster is a group of building blocks that represents one part of the neighborhood) from two districts were selected from Makkah to represent the different urban fabric configurations, as highlighted in Figure 2C. The AlSharashef district represents the old, organic fabric with a conventional cul-de-sac pattern, while the AlEskan district represents the deformed iron-grid urban fabric with a curvilinear loop pattern. Four clusters in the AlSharashef and AlEskan districts. Cluster \#1 represents the old organic/compact urban fabric from the AlSharashef district, Cluster \#2 represents the high-rise building area in the AlSharashef district, Cluster \#3 represents the fully occupied modern urban design fabric with a cluster design, and Cluster \#4 represents under-construction modern design fabric with large areas of empty land.

\subsection{Materials and Methods}

Several research techniques and methods were employed in the current research, including data collection; an analytical literature review; the retrieval of LST from multitemporal Landsat 8 images using ENVI 5.3 (Harris Geospatial); context analysis using Meteonorm (Meteonorm is a unique combination of reliable data sources and high-quality calculation models and offers access to typical years and historical time series: https: // meteonorm.com/, accessed on 2 March 2021), Weather Tool (Weather Tool is a graphicbased computer program to analyze the hourly climate data developed by Square One research: https:/ / the-weather-tool.software.informer.com/ (accessed on 2 March 2021) and recognizes a wide range of international weather file formats, such as fixed format weather files, separated value files, and linear row data files; in addition, it allows the 
user to specify customized data import formats from ASCII files, allowing the use of a wide range of climatic data files [53]. Marsh, A. The thermal simulation engine, Autodesk, Inc.: 2008.), Climate Consultant software (Climate Consultant is a graphic-based computer program that helps architects, builders, contractors, homeowners, and students understand their local climate: http: / / www.energy-design-tools.aud.ucla.edu/climate-consultant/ request-climate-consultant.php, accessed on 2 March 2021), and Space Syntax (Space syntax is a Spatial Analysis software: https://www.spacesyntax.net/software/, accessed on 2 March 2021) (DepthmapX); and statistical analysis using Statistical Package for the Social Sciences (SPSS) (SPSS stands for Statistical Package for the Social Sciences; the SPSS software platform offers advanced statistical analysis: https:/ / www.ibm.com/sa-en/ analytics/spss-statistics-software, accessed on 2 March 2021).

Comparing the UHIs between two clusters could be conducted by using either land surface temperatures to compare the SUHIs or air temperatures $(\Delta \mathrm{T})$ to compare the urban canopy layer (UCL) or the urban boundary layer (UBL). In the current research, land surface temperature images with no apparent cloud acquired from two satellite images from Landsat 8 (22 December 2019 (Winter) and 18 June 2020 (Summer)) were provided by United States Geological Survey (USGS) [54]. The thermal infrared sensor (TIRS) was selected for the estimation of LST. The TIRS instrument onboard the Landsat 8 satellite observes the LST by using the split-window thermal infrared channels (CH10: 10.6 to $11.2 \mu \mathrm{m}$; CH11: 11.5 to $12.5 \mu \mathrm{m}$ ) at a spatial resolution of $100 \mathrm{~m}$. The Landsat 8 TIRS has advantages over the TIRS predecessors, Landsat 5 and Landsat 7, in that it (1) has two thermal infrared channels, thus enabling LST retrieval using the split-window algorithm; (2) has a narrower bandwidth and, therefore, provides more detailed land surface information $[55,56]$. The fact that the estimation of LST from satellite images requires knowledge of atmospheric profiles during image acquisition adds significant uncertainty to LST retrieval. The split-window algorithm largely solved this complexity by removing the atmospheric effect through applying differential atmospheric absorption in the two TIRS channels centered at about 11 and $12 \mu \mathrm{m}$, and, therefore, the linear or nonlinear combination of the brightness temperatures in channel can be accurately applied for LST retrieval [56].

The LST using the split-window algorithm can be estimated as follows:

$$
\mathrm{LST}=\mathrm{Tb} /(1+(\lambda+\mathrm{Tb} / \rho) \times \operatorname{Ln} \varepsilon)
$$

where LST is the land surface temperature in kelvin; Tb is the satellite brightness temperature; $\lambda$ is the central-band wavelength of emitted radiance; and $\rho$ is $h \times(\mathrm{c} / \sigma)$, where $\sigma$ is Boltzmann's constant $\left(1.38 \times 10^{-23} \mathrm{~J} / \mathrm{K}\right)$, h is Plank's constant $\left(6.626 \times 10^{-34} \mathrm{~J} \times \mathrm{s}\right)$, and c is the speed of light $\left(2.998 \times 10^{8} \mathrm{~m} / \mathrm{s}\right)$.

The result of this equation was converted to degrees Celsius $\left({ }^{\circ} \mathrm{C}\right)$ by using the LST equation $\left({ }^{\circ} \mathrm{C}\right)=\mathrm{LST}-273.15$ for the two compared districts to visualize and analyze their differences in terms of UHI phenomena. The tabulated data on the two districts in two different months, June and December, representing the hottest and coldest months in Makkah, were acquired and analyzed using SPSS and Microsoft Excel software. Paired-sample $t$-testing for the two months confirmed a significant difference between the distributions of the LST in the two districts, where the $p$-value was smaller than 0.05 (In most analyses, an alpha value of 0.05 is used as the cut-off for significance. If the p-value is less than 0.05 , this confirms the hypothesis that there is a significant difference between the means. If the p-value is larger than 0.05 , this proves the null hypothesis of no significant difference existing.) [57].

The four clusters were evaluated using Space Syntax through different analytical axial maps. Space Syntax evaluates the spatial structure of the street network using graph-based parameters and statistical values. DepthmapX is a multi-platform software product that can perform spatial network analyses of factors that significantly affect social behaviors. It has been found that the relationship between Space Syntax graph-based measures of street networks and pedestrian flows is very strong [58]. Moreover, the integration values state 
the movement and density potentials of a city, where the correlation between the potential rates and the observed rates is 60-80\% [59], as quoted in [60].

An hourly climate data file synthesized by Crawley and Lawrie [61] was adapted and compared to another synthesized using Meteonorm software. On analyzing the hourly climate data of Makkah using Weather Tool [62,63], a summary of the climate conditions could be drawn.

\section{Results and Discussion}

Analyzing the speeds, directions, and frequencies of wind in Makkah revealed that the direction of the prevailing wind is north with the highest frequency and speed in Makkah, reaching $15 \mathrm{Km} / \mathrm{h}$. A high speed and frequency of wind also come from the southwest, reaching $6 \mathrm{~km} / \mathrm{h}$ (Figure 3 ).

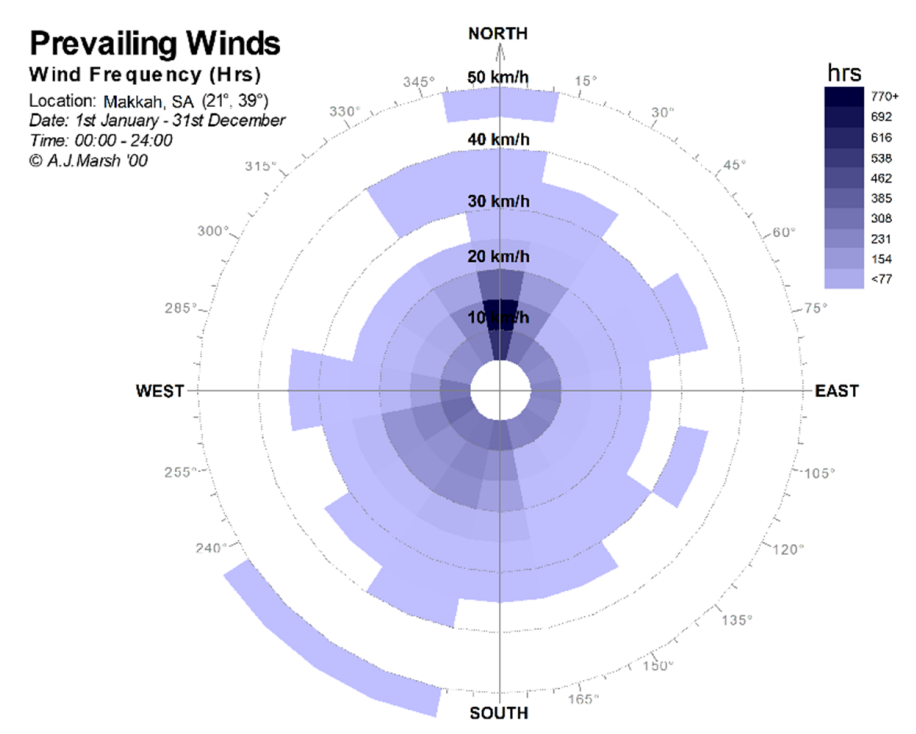

Figure 3. Windrose for Makkah, from Weather Tool.

Analysis of the diurnal hourly average air temperature (Figure 4), which employed the comfort: thermal neutrality model, showed that the thermal comfort zone in Makkah city ranges between 18 and $31^{\circ} \mathrm{C}$. The Weather Tool, which incorporates Humphreys adaptive algorithms [64], enables the consideration of adaptive actions taken by building occupants. Additionally, the analysis showed that most of the annual air temperature values lie outside the comfort zone, with a maximum of $48^{\circ} \mathrm{C}$ in June, a minimum of $14{ }^{\circ} \mathrm{C}$ in January, and an average air temperature of $31^{\circ} \mathrm{C}$ (Figure 4).

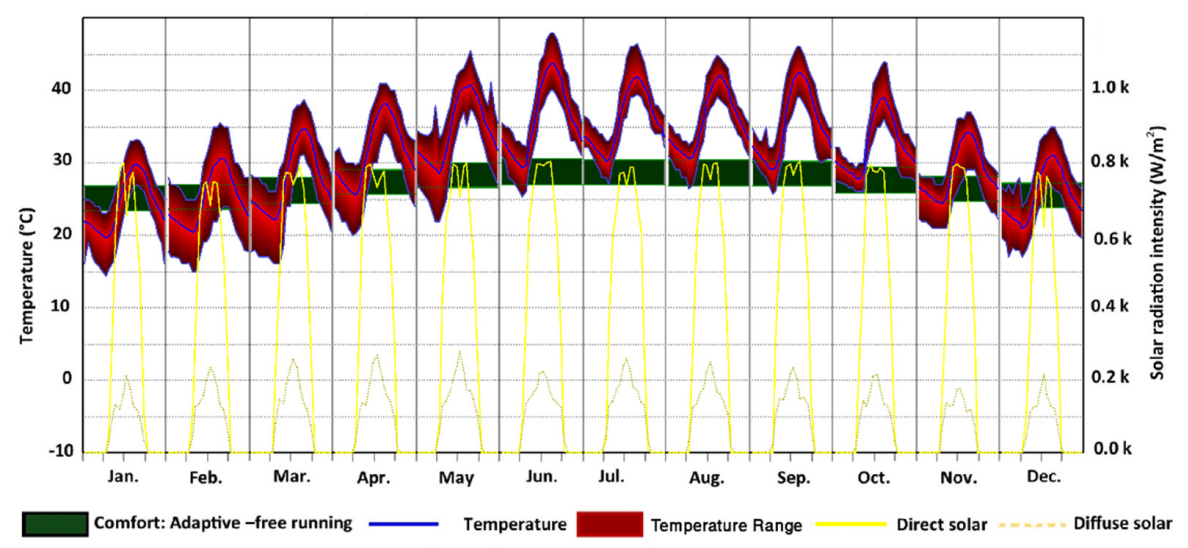

Figure 4. Diurnal hourly averages air temperature in Makkah, from Weather Tool. 
The Weather Tool can suggest the most efficient passive strategies that could be employed to enhance the environmental performance of the context using the Psychrometric Chart. On analyzing the hourly climatic data of Makkah, the Weather Tool revealed that thermal mass effects, night purge ventilation, indirect evaporative cooling, and natural ventilation are the most effective passive strategies for Makkah. An investigation of the comfort percentages-as an indicator of the LST-using the different passive strategies in Makkah revealed that natural ventilation could enhance the comfort percentage by $38 \%$, thermal mass by $29 \%$, indirect evaporative cooling by $14 \%$, and night purge ventilation by $5 \%$. Figure 5 shows the percentage of the comfort before applying the passive strategy and after applying it. To consider the significant importance of the natural ventilation, street orientation should be oriented to the prevailing wind direction when deciding on the urban fabric type and geometry.

\section{Comfort Percentages \\ NAME: Makkah \\ LOCATION: SA \\ WEEKDAYS: 00:00 - 24:00 Hrs WEEKENDS: 00:00 - 24:00 $\mathrm{Hrs}$ \\ POSITION: $21^{\circ}, 39^{\circ}$ \\ (C) A.J.Marsh '00}

\section{CLIMATE: Af}

Tropical moist climate where precipitation occurs all year long. Monthly temperature variation is less than 3 degrees Celsius. Intense heating and humidity cause aftemoon clouds almost every day.

Daily highs about $32^{\circ} \mathrm{C}$ while night time temperatures average $22^{\circ} \mathrm{C}$
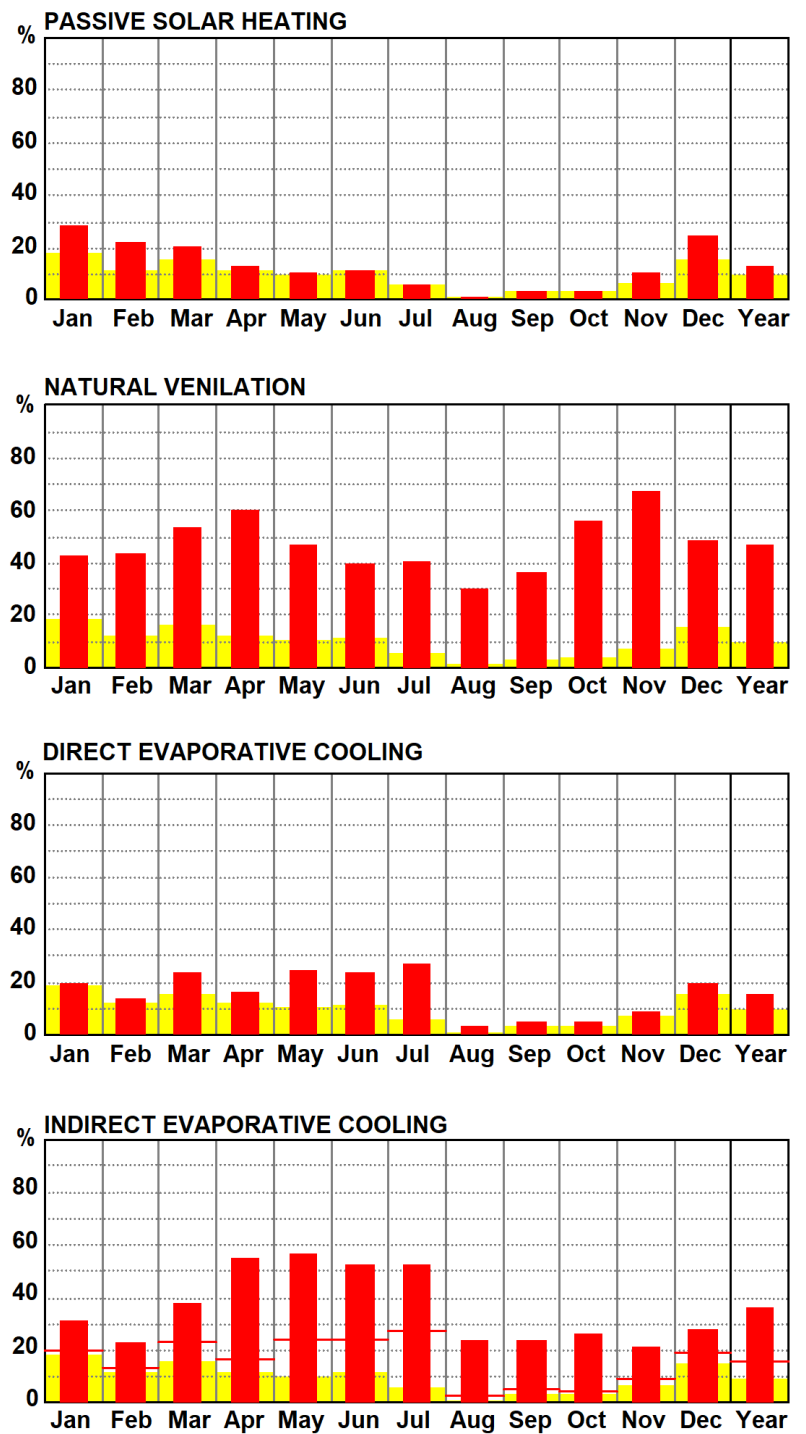
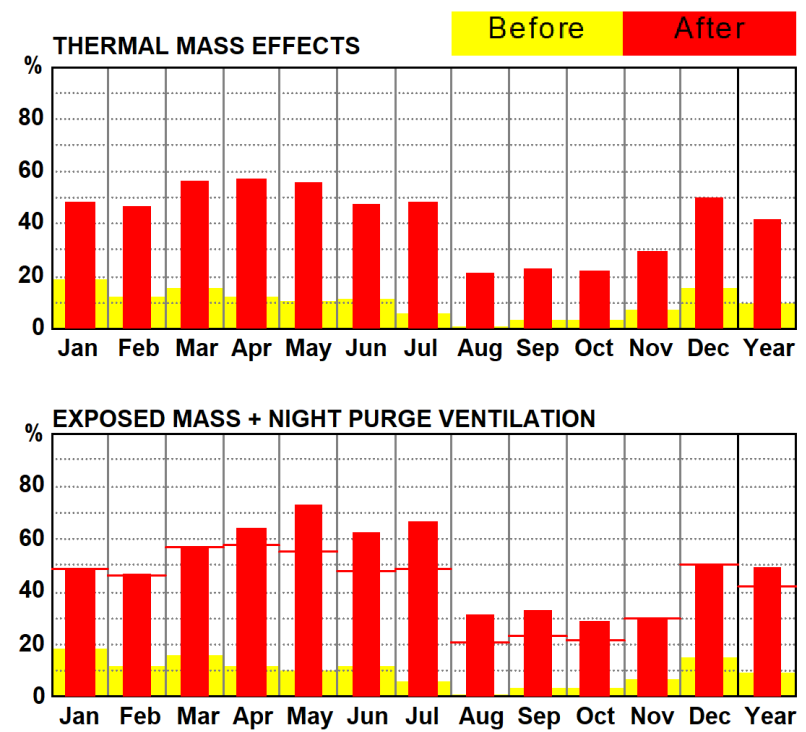

Figure 5. Comfort percentages using different passive strategies in Makkah, from the Weather Tool.

The spatial characteristics of the street network were obtained in the digital CAD file format from the Prince Khalid Al-Faisal Chair for Developing Makkah Al-Mukarramah and the Holy Places at Umm Al-Qura University [65] and were analyzed using the Space Syntax software. The analysis of the urban characteristics of the different clusters in the two districts show that the axial lines have different levels (red, orange, yellow, green, blue, and indigo): red lines have the highest value, while orange lines have a middle value, and 
the indigo lines have the lowest value. The dark red and orange lines in AlSharashef and AlEskan are highly accessible, integrated, and connected areas. The green and blue axes are the less accessible, integrated, and connected spatial structure areas. A high value of integration indicates that the street accessibility of these parts for pedestrians is more than that of other segments. Blue and indigo segments are the most segregated parts-they are not integrated into the entire city street network. Segregated vs. integrated indicates two contrasting types of spatial layouts; the former indicates that all spaces are far away from all the others, and the latter indicates that all spaces are close to all the others [66,67]. On analyzing the values statistically, it was found that the AlSharashef cluster shows higher values than the AlEskan cluster in terms of local accessibility, connectivity, and integration. In comparison, it provided lower values in terms of global accessibility (Figure 6). It is obvious from the maps that few straight linear streets in the AlEskan district have higher values in terms of accessibility, connectivity, and integration, while the rest of the streets have lower values, which indicates more segregation of spaces. This indicates that the internal integration of the organic fabric with a conventional cul-de-sac pattern is higher than that of the deformed iron-grid urban fabric with a curvilinear loop pattern, which has been proved in previous studies [26-28,68-72]. It is worth mentioning here that the high value of connectivity and integrations allows more shade and shadow, enhancing walkability levels and creating differential pressure. The latter, in turn, forces the air to move [73-75]. This proves the efficiency of the organic urban fabrics in hot arid zones in terms of thermal performance and urban efficiency.

The two districts were compared visually and statistically using the land surface temperature (LST) in general for the two districts to study the urban fabric's effect on the UHI performance in both districts. Figure 7 shows the distribution of LSTs in the AlSharashef and AlEskan districts in June and December.

The LST data extracted from the Landsat 8 images in each district in June and December (i.e., 3673 temperature values in each month for each district) were analyzed using the SPSS, and the results revealed that the LST was generally lower in the AlShrashef district than the AlEskan district, as summarized in Tables 2 and 3.

Table 2. Summary of temperature values in the AlShrashef and AlEskan districts in June and December.

\begin{tabular}{cccccc}
\hline & District & \multicolumn{2}{c}{ AlSharashef District } & \multicolumn{2}{c}{ AlEskan District } \\
\cline { 3 - 6 } Temp. & & June & December & June & December \\
\hline & Mean & 43.39 & 29.98 & 45.23 & 30.72 \\
Min. & 39.32 & 26.23 & 43.45 & 28.08 \\
Max. & 46.72 & 33.83 & 47.38 & 33.34 \\
\hline
\end{tabular}

Table 3. Variation testing using paired-sample t-testing.

\begin{tabular}{ccccc}
\hline \multicolumn{2}{c}{ Comparison Item } & \multicolumn{2}{c}{ June } & December \\
\hline & AlSharashef & AlEskan & AlSharashef & AlEskan \\
\hline Mean temp. & 43.39 & 45.23 & 29.98 & 30.72 \\
\hline \multicolumn{2}{c}{$t$-Test } & \multicolumn{2}{c}{$\mathrm{S}$} & $p=<0.001$ \\
\hline $\begin{array}{c}\text { The difference between the two sets of LSTs of the } \\
\text { two districts in June and December (S = significant) }\end{array}$ & & & $\mathrm{S}$ \\
\hline
\end{tabular}




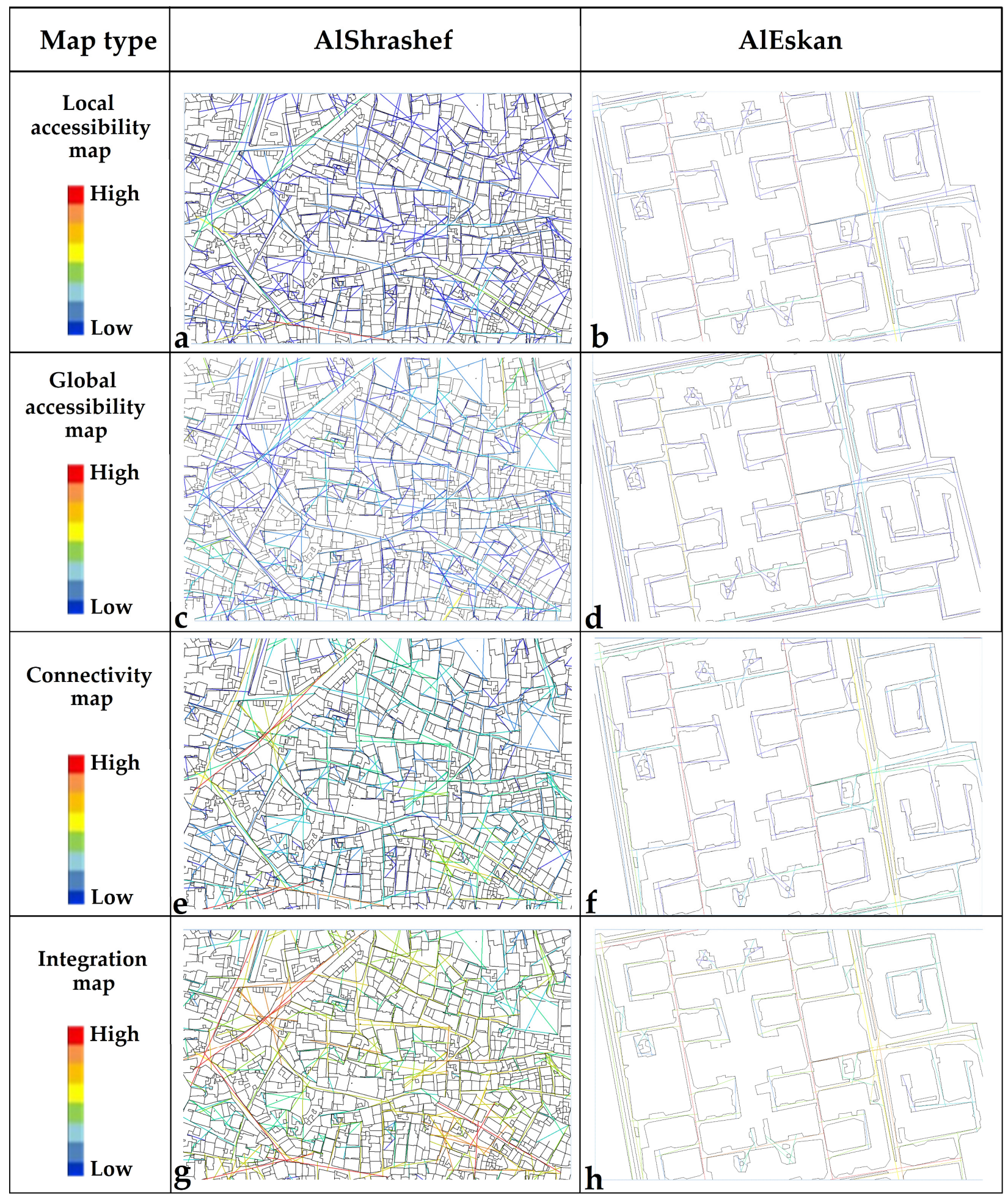

Figure 6. Comparison between the two clusters in terms of accessibility, connectivity, and integration using Space Syntax. (a) Average local accessibility value: 2971.28; (b) average local accessibility value: 281.64 ; (c) average global accessibility value: 43.9 ; (d) average global accessibility value: 47.56 ; (e) average connectivity value: 4.45 ; (f) average connectivity value: 3.53; (g) average integration value: 1.77; $(\mathbf{h})$ average integration value: 1.7. 

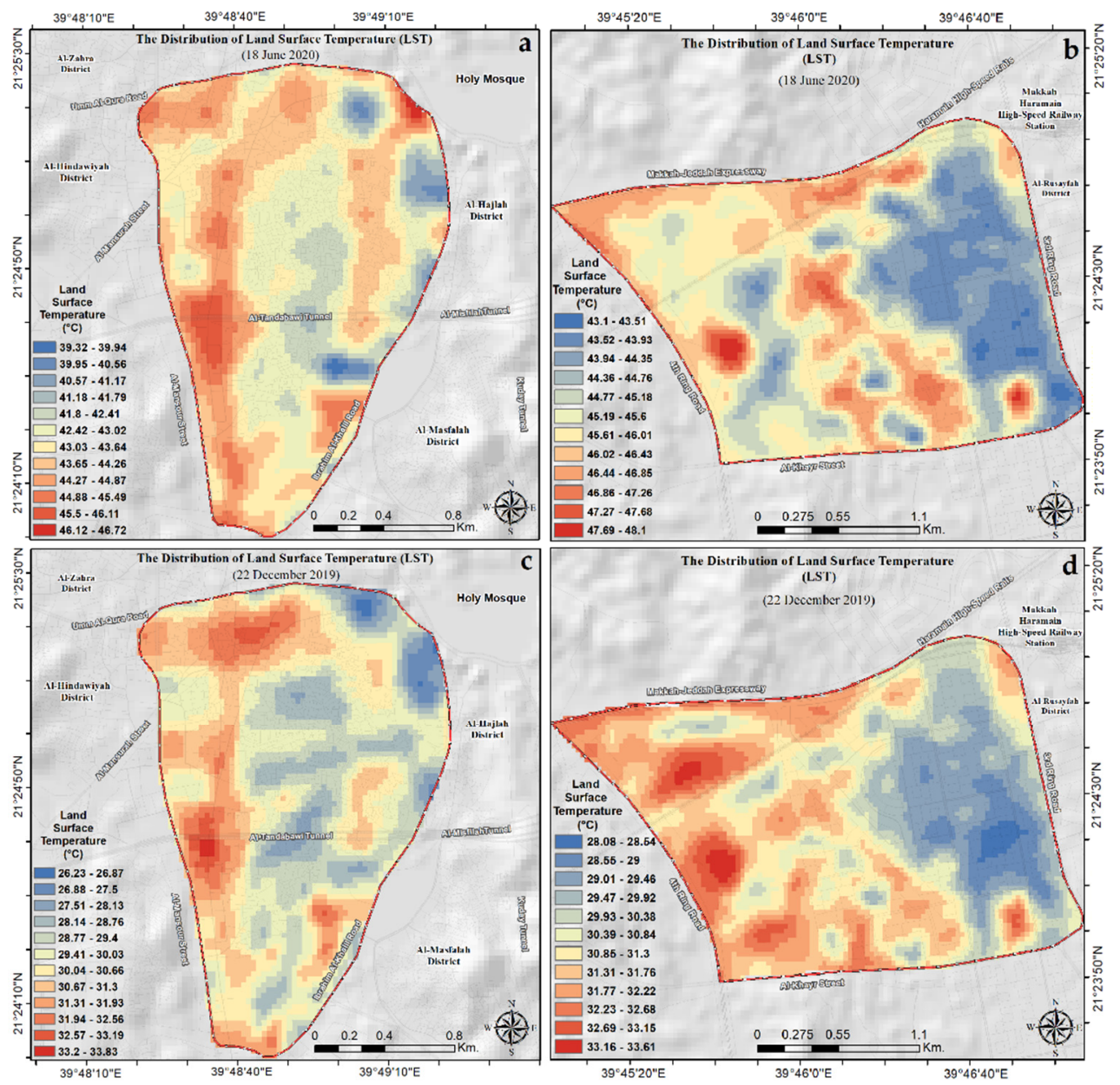

Figure 7. The land surface temperature (LST) distributions in the AlSharashef and AlEskan districts in June and December: (a) AlSharashef, June; (b) AlEskan, June; (c) AlSharashef, December; (d) AlEskan, December.

For further analysis of the two districts, four clusters were selected from the two districts for comparison. The LSTs of the four clusters are compared in Figure 8. It could be concluded that the LST was higher in the under-construction area than in the fully occupied areas, with the difference reaching $4{ }^{\circ} \mathrm{C}$. Given that Saudi Arabia is a desert country, with its surface area mainly covered by barren lands [76], and exhibits a wide range of lithological units with different thermal capacities, such as the rock outcrops of diorite, quartz diorite in the study area, the areas still under construction can produce higher LST (Figures 2B, 7 and 8), while occupied urban areas help to reduce the UHI phenomenon. Likewise, this inversion in the UHI phenomenon is reported in the nearby Abu Dhabi city, where the downtown of the city shows $5-6 \mathrm{~K}$ and $2-3 \mathrm{~K}$ colder LST than the suburbs during the summer and winter seasons, respectively [77]. These findings indicate that in desert environments, the UHI can deviate from the standard distribution, where high populated areas show relatively higher LST compared to the surrounding countryside as previously reported from global analyses [78] and several case studies [28,79] worldwide. 

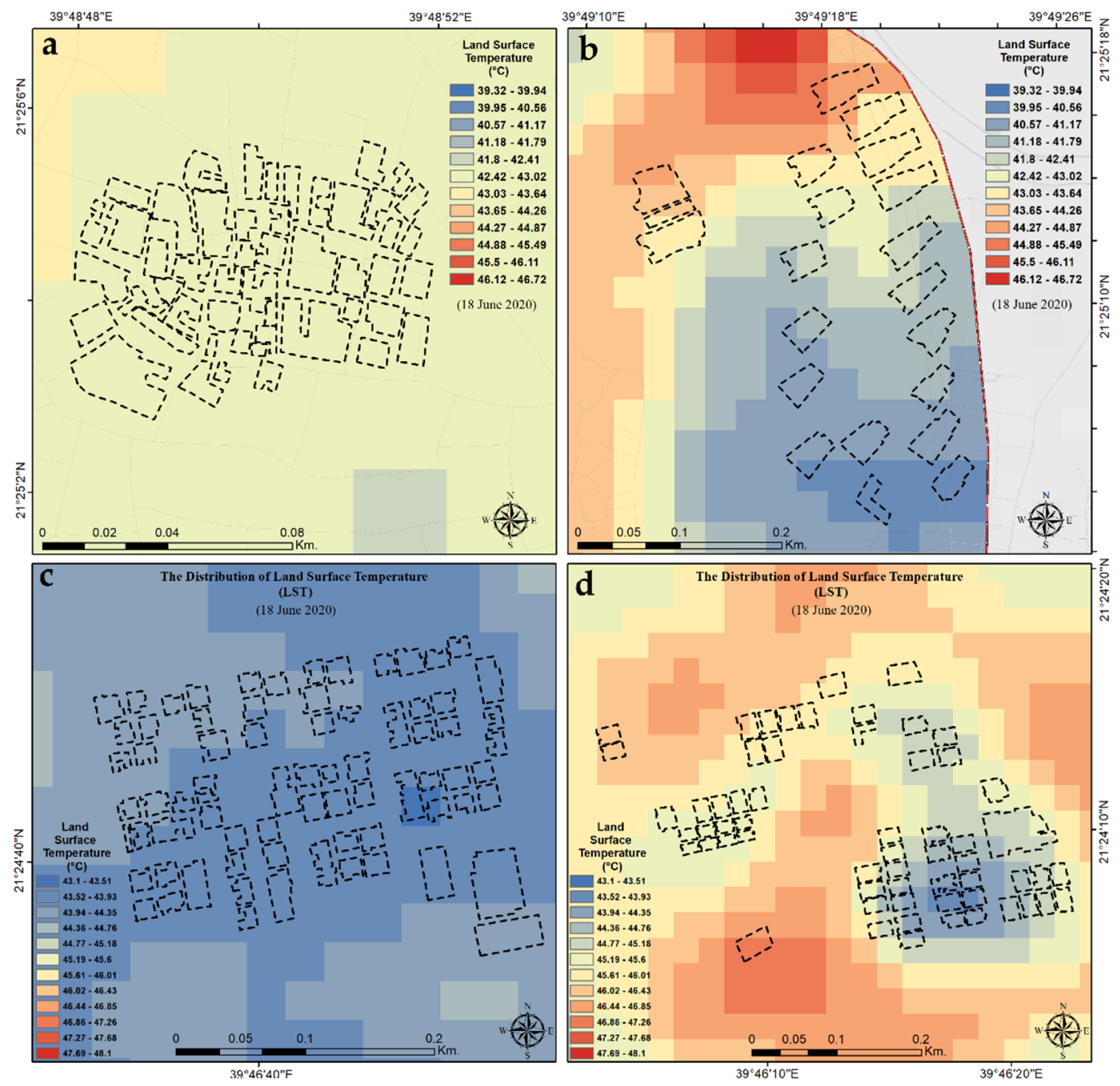

Figure 8. Comparisons between the LSTs of the four clusters: (a) AlSharashef \#1, (b) AlSharashef \#2, (c) AlEskan \#1, and (d) AlEskan \#2.

Another detailed comparison was conducted for the LSTs of the two occupied clusters in the two districts-AlShrashef \#1 and AlEskan \#1-in both the summer and the winter. These two clusters represent the two main urban fabrics in Makkah: the old/organic and the deformed iron-grid urban fabric with clusters. On analyzing 486 temperature values in each cluster in June and December, representing the hottest and the coldest months, respectively, using SPSS, the results (Tables 4 and 5) confirmed that the LST in the AlShrashef cluster, representing an organic/compact design, was lower than that in the AlEskan cluster, representing modern urban fabric, by about $1^{\circ} \mathrm{C}$ at all times. This confirms the discussion of the urban morphology and the urban geometry where compact buildings offer a high ratio of shading that reduces the LST and air temperature. Similar findings were reported on the global scale [80], regional scale (e.g., across China) [81], and also on the very local scale (e.g., the University of Sharjah, UAE) [82]. Additionally, local material (mud and clay) with high thermal mass absorbs the heat and reduces the reflection by minimizing the LST. 
Table 4. A summary of the LST comparison between the two clusters in June and December.

\begin{tabular}{cccccc}
\hline \multirow{2}{*}{ Temp. District } & \multicolumn{2}{c}{ AlShrashef Cluster } & \multicolumn{2}{c}{ AlEskan Cluster } \\
\cline { 3 - 6 } & & June & December & June & December \\
\hline & Mean & 42.51 & 27.82 & 43.68 & 29.33 \\
Min. & 42.42 & 26.88 & 43.1 & 28.08 \\
Max. & 43.21 & 29.45 & 44.76 & 31.04 \\
\hline
\end{tabular}

Table 5. Variation testing using paired-sample $t$-testing.

\begin{tabular}{ccccc}
\hline \multirow{2}{*}{ Comparison Item } & \multicolumn{2}{c}{ June } & \multicolumn{2}{c}{ December } \\
\cline { 2 - 5 } & AlShrashef & AlEskan & AlShrashef & AlEskan \\
\hline Mean temp. & 42.51 & 43.68 & 27.82 & 29.33 \\
\hline t-Test & $p \leq 0.001$ & & & $\mathrm{~S}$ \\
\hline $\begin{array}{c}\text { The difference between the two sets of } \\
\text { LSTs of the two districts in June and } \\
\text { December (S = Significant) }\end{array}$ & \multicolumn{2}{c}{$\mathrm{S}$} & & \\
\hline
\end{tabular}

Paired-sample $t$-testing for the two months confirmed a significant difference between the distributions of the LST in the two districts, where the $p$-value was smaller than 0.05 . This confirms that the organic/compact urban design fabric is still better than the deformed iron-grid urban fabric in terms of thermal performance. In Supplementary Materials.

\section{Conclusions}

The current research was concerned with analyzing the UHI using remote sensingderived LST as well as examining the impact of different urban fabrics on the UHI distribution, using two districts in Makkah city, namely, AlEskan and Al-Sharshaf districts, as test sites. Several conclusions can be drawn from this research, as follows: (1) the mean temperature for the AlEskan district was $1-1.5{ }^{\circ} \mathrm{C}$ higher than that of the Al-Sharshaf district; (2) given that Saudi Arabia is a desert country, with its surface area mainly covered by barren lands, and exhibits a wide range of lithological units with different thermal capacities, such as the rock outcrops of diorite, quartz diorite in the study area, the desert and areas under construction can produce higher LST; (3) urban fabric configuration can significantly affect the UHI distribution, where organic urban fabric with narrow streets provides more shading than other types of urban fabric, thus decreasing the UHI effects. These findings, however, are specific to the test site; however, they shed light on the significance of integrating remote sensing and spatial network analysis in urban planning to better understand and mitigate the UHI in hyper-arid desert environments.

Supplementary Materials: The following are available online at https:/ /www.mdpi.com/article/10 $.3390 / \mathrm{rs} 13101941 / \mathrm{s} 1$. Summary of temperature in Dec, Summary of temperature in June, Variance in Dec, Variance in June and Test of correlation in June.

Author Contributions: Conceptualization, M.M. and A.M.; methodology, M.M., A.M., A.O., and A.Z.A.; software M.M., A.M., and A.O.; validation, M.M., A.M., A.O., and A.Z.A.; formal analysis, M.M. and A.M.; writing-original draft preparation, M.M., A.M., and A.O.; writing-review and editing, M.M., A.M., A.O., and A.Z.A.; visualization, M.M., A.M., A.O., and A.Z.A.; supervision, M.M.; project administration, A.M.; funding acquisition, M.M. and A.M. All authors have read and agreed to the published version of the manuscript.

Funding: This research was funded by the Deanship of Scientific Research and Prince Khalid Al-Faisal Chair for Developing Makkah Al-Mukarramah and the Holy Places at Umm Al-Qura University (project \# DSRUQU.PKC-41-4).

Institutional Review Board Statement: Not applicable.

Informed Consent Statement: Not applicable. 
Data Availability Statement: The data presented in this study are available on request from the corresponding author, and most of the data are provided in the supplementary file.

Acknowledgments: The authors are grateful for the valuable comments provided by the editor and four anonymous reviewers, which were used to improve the quality of this work.

Conflicts of Interest: The authors declare no conflict of interest.

\section{References}

1. United Nations. World Population Projected to Reach 9.7 Billion by 2050. Available online: http://www.un.org/en/development/ desa/news/population/2015-report.html (accessed on 27 February 2021).

2. Mohamed, M.; Fatani, K.; Khateeb, S.A. Sustainable socio-cultural guidelines for neighborhood design in jeddah. Procedia J. Environ. Sci. Green Urban. 2017, 37, 584-593. [CrossRef]

3. Fatani, K.; Mohamed, M.; Al-Khateeb, S. Survey Based Sustainable Socio-Cultural Guidelines for Neighbourhood Design in Jeddah. IOP Conf. Ser. Earth Environ. Sci. 2019, 385, 012050. [CrossRef]

4. UN-Habitat. Urban Themes. Available online: https://unhabitat.org/urban-themes/climate-change/ (accessed on 6 March 2021).

5. UN-Habitat. City Prosperity Initiative (CPI). Available online: http://cpi.unhabitat.org/ (accessed on 22 February 2021).

6. Li, J.; Zheng, B.; Shen, W.; Xiang, Y.; Chen, X.; Qi, Z. Cooling and energy-saving performance of different green wall design: A simulation study of a block. Energies 2019, 12, 2912. [CrossRef]

7. Hellström, T. Dimensions of environmentally sustainable innovation: The structure of eco-innovation concepts. Sustain. Dev. 2007, 15, 148-159. [CrossRef]

8. Lin, P.; Gou, Z.; Lau, S.; Qin, H. The impact of urban design descriptors on outdoor thermal environment: A literature review. Energies 2017, 10, 2151. [CrossRef]

9. Aram, F.; Solgi, E.; Higueras García, E.; Mosavi, A.; Várkonyi-Kóczy, A.R. The cooling effect of large-scale urban parks on surrounding area thermal comfort. Energies 2019, 12, 3904. [CrossRef]

10. Ferguson, B.; Fisher, K.; Golden, J.; Hair, L.; Haselbach, L.; Hitchcock, D.; Kaloush, K.; Pomerantz, M.; Tran, N.; Waye, D. Reducing Urban Heat Islands_Compendium of Strategies-Cool Pavements; The National Academies of Sciences, Engineering, and Medicine: Washington, DC, USA, 2008.

11. Sailor, D. Mitigation of Urban Heat Islands-Recent Progress and Future Prospects. 2006. Available online: https://ams.confex. com/ams/Annual2006/techprogram/paper_105264.htm (accessed on 22 February 2021).

12. Rajagopalan, P.; Lim, K.C.; Jamei, E. Urban heat island and wind flow characteristics of a tropical city. Sol. Energy 2014, 107, 159-170. [CrossRef]

13. Nuruzzaman, M. Urban Heat Island: Causes, Effects and Mitigation Measures-A Review. Int. J. Environ. Monit. Anal. 2015, 3. [CrossRef]

14. Mohamed, M. Traditional ways of dealing with climate in Egypt. In Proceedings of the The Seventh International Conference of Sustainable Architecture and Urban Development (SAUD 2010), Amman, Jordan, 12-14 July 2010; pp. 247-266.

15. Mohamed, M.; Gado, T.; Osman, M. Investigating the intelligence of the low-tech earth architecture of the Sahara: A feasibility study from the western desert of Egypt. Intell. Build. Int. (IBI) 2010, 2, 179-197. [CrossRef]

16. Wang, Y.; Berardi, U.; Akbari, H. Comparing the effects of urban heat island mitigation strategies for Toronto, Canada. Energy Build. 2016, 114, 2-19. [CrossRef]

17. Siti Halipah, I.; Ibrahim, N.; Wahid, J.; Goh, N.; Koesmeri, D.; Mohd Nawi, M.N. The impact of road pavement on Urban Heat Island (UHI) phenomenon. Int. J. Technol. 2018, 9, 1597. [CrossRef]

18. Wonorahardjo, S.; Sutjahja, I.M.; Mardiyati, Y.; Andoni, H.; Thomas, D.; Achsani, R.A.; Steven, S. Characterising thermal behaviour of buildings and its effect on urban heat island in tropical areas. Int. J. Energy Environ. Eng. 2019. [CrossRef]

19. Coseo, P.J.; Larsen, L. How factors of land use/land cover, building configuration, and adjacent heat sources and sinks explain Urban Heat Islands in Chicago. Landsc. Urban Plan. 2014, 125, 117-129. [CrossRef]

20. Arrau, C.P.; Peña, M.A. Heat Island Types. Available online: https://www.urbanheatislands.com/heat-island-types (accessed on 6 March 2021).

21. Wong, E. Reducing urban heat islands: Compendium of strategies-Urban heat island basics. In The Climate Protection Partnership Division; Environmental Protection Agency's Office of Atmospheric Programs: Washington, DC, USA, 2014.

22. Maleki, A.; Mahdavi, A. Evaluation of Urban Heat Islands mitigation strategies using 3dimentional urban micro-climate model envi-met. Asian J. Civ. Eng. (BHRC) 2016, 17, 357-371.

23. Tan, J.; Zheng, Y.; Tang, X.; Guo, C.; Li, L.; Song, G.; Zhen, X.; Yuan, D.; Kalkstein, A.J.; Li, F. The urban heat island and its impact on heat waves and human health in Shanghai. Int. J. Biometeorol. 2010, 54, 75-84. [CrossRef] [PubMed]

24. Li, D.; Bou-Zeid, E. Synergistic Interactions between Urban Heat Islands and Heat Waves: The Impact in Cities Is Larger than the Sum of Its Parts*. J. Appl. Meteorol. Climatol. 2013, 52, 2051-2064. [CrossRef]

25. Amorim, M.C.d.C.T. Daily evolution of urban heat islands in a Brazilian tropical continental climate during dry and rainy periods. Urban Clim. 2020, 34, 100715. [CrossRef]

26. Anjos, M.; Targino, A.C.; Krecl, P.; Oukawa, G.Y.; Braga, R.F. Analysis of the urban heat island under different synoptic patterns using local climate zones. Build. Environ. 2020, 185, 107268. [CrossRef] 
27. Elliot, T.; Babí Almenar, J.; Rugani, B. Modelling the relationships between urban land cover change and local climate regulation to estimate urban heat island effect. Urban For. Urban Green. 2020, 50, 126650. [CrossRef]

28. Liu, Y.; Li, Q.; Yang, L.; Mu, K.; Zhang, M.; Liu, J. Urban heat island effects of various urban morphologies under regional climate conditions. Sci. Total Environ. 2020, 743, 140589. [CrossRef] [PubMed]

29. Parker, J. The Leeds urban heat island and its implications for energy use and thermal comfort. Energy Build. 2020, 110636. [CrossRef]

30. Pioppi, B.; Pigliautile, I.; Pisello, A.L. Human-centric microclimate analysis of Urban Heat Island: Wearable sensing and data-driven techniques for identifying mitigation strategies in New York City. Urban Clim. 2020, 34, 100716. [CrossRef]

31. Zinzi, M.; Agnoli, S.; Burattini, C.; Mattoni, B. On the thermal response of buildings under the synergic effect of heat waves and urban heat island. Sol. Energy 2020, 211, 1270-1282. [CrossRef]

32. Chen, F. Urban morphology and citizens' life. In Encyclopedia of Quality of Life and Well-Being Research; Michalos, A.C., Ed.; Springer Netherlands: Dordrecht, The Netherlands, 2014; pp. 6850-6855.

33. Marshall, W.E.A.N.W.G. Street network types and road safety. Urban Des. Int. 2010, 15, 133-147. [CrossRef]

34. Battisti, A. Bioclimatic architecture and urban morphology. Studies on intermediate urban open spaces. Energies 2020, 13, 5819. [CrossRef]

35. Mohajerani, A.; Bakaric, J.; Jeffrey-Bailey, T. The urban heat island effect, its causes, and mitigation, with reference to the thermal properties of asphalt concrete. J. Environ. Manag. 2017, 197, 522-538. [CrossRef] [PubMed]

36. Rode, P.; Keim, C.; Robazza, G.; Viejo, P.; Schofield, J. Cities and energy: Urban morphology and residential heat-energy demand. Environ. Plan. B Plan. Des. 2014, 41, 138-162. [CrossRef]

37. Jung, S.; Yoon, S. Changes in sunlight and outdoor thermal environment conditions based on the layout plan of flat type apartment houses. Energies 2015, 8, 9155-9172. [CrossRef]

38. Liang, Z.; Wang, Y.; Huang, J.; Wei, F.; Wu, S.; Shen, J.; Sun, F.; Li, S. Seasonal and diurnal variations in the relationships between urban form and the urban heat island effect. Energies 2020, 13, 5909. [CrossRef]

39. Mohammed, Y.; Salman, A. Effect of urban geometry and green area on the formation of the urban heat island in Baghdad city. MATEC Web. Conf. 2018, 162, 05025. [CrossRef]

40. Guo, Y.-j.; Han, J.-j.; Zhao, X.; Dai, X.-y.; Zhang, H. Understanding the role of optimized land use/land cover components in mitigating summertime intra-surface urban heat island effect: A study on downtown Shanghai, China. Energies 2020, 13, 1678. [CrossRef]

41. Elkadiri, R.; Manche, C.; Sultan, M.; Al-Dousari, A.; Uddin, S.; Chouinard, K.; Abotalib, A.Z. Development of a coupled spatiotemporal algal bloom model for coastal areas: A remote sensing and data mining-based approach. IEEE J. Sel. Top. Appl. Earth Obs. Remote Sens. 2016, 9, 5159-5171. [CrossRef]

42. Zhou, D.; Xiao, J.; Bonafoni, S.; Berger, C.; Deilami, K.; Zhou, Y.; Frolking, S.; Yao, R.; Qiao, Z.; Sobrino, J.A. Satellite remote sensing of surface urban heat islands: Progress, challenges, and perspectives. Remote Sens. Environ. 2019, 11, 48. [CrossRef]

43. Rao, P.K. Remote sensing of urban "heat islands" from an environmental satellite. Bull. Am. Meteorol. Soc. 1972, 53, 647-648.

44. Carnahan, W.H.; Larson, R.C. An analysis of an urban heat sink. Remote Sens. Environ. 1990, 33, 65-71. [CrossRef]

45. Nichol, J. Remote sensing of urban heat islands by day and night. Photogramm. Eng. Remote Sens. 2005, 71, 613-621. [CrossRef]

46. Almazroui, M.; Nazrul Islam, M.; Athar, H.; Jones, P.D.; Rahman, M.A. Recent climate change in the Arabian Peninsula: Annual rainfall and temperature analysis of Saudi Arabia for 1978-2009. Int. J. Climatol. 2012, 32, 953-966. [CrossRef]

47. Worldometer. Saudi Arabia Population. Available online: https://www.worldometers.info/world-population/saudi-arabiapopulation/ (accessed on 21 February 2021).

48. Greenwood, W.R.; Hadley, D.G.; Anderson, R.E.; Fleck, R.J.; Schmidt, D.L. A Discussion on global tec-tonics in Proterozoic times-Late Proterozoic cratonization in southwest Saudi Arabia Philosophical Transac-tions of the Royal Society of London. Philos. Trans. R. Soc. Lond. Ser. AMath. Phys. Sci. 1976, 280, 517-527. [CrossRef]

49. Moore, T.A.; Al-Rehaili, M.H. Geologic Map of the Makkah Quadrangle, Saudi Arabian Directorate General of Mineral Resources Geoscience Map GM-107C. 1989. Available online: https://www.scirp.org/(S(351jmbntvnsjt1aadkposzje))/reference/ ReferencesPapers.aspx?ReferenceID=1611733 (accessed on 21 February 2021).

50. Abotalib, A.Z.; Mohamed, R.S.A.. Surface evidences supporting a probable new concept for the river systems evolution in Egypt: A remote sensing overview. Environ. Earth Sci. 2013, 69, 1621-1635. [CrossRef]

51. Othman, A.; Shaaban, F.; Abotalib, A.Z.; El-Saoud, W.A.; Gabr, S.S.; Habeebullah, T.; Hegazy, D. Hazard assessment of rockfalls in mountainous urban areas, western saudi arabia. Arab. J. Sci. Eng. 2020. [CrossRef]

52. TopView. Makkah. Available online: https://ngmdb.usgs.gov/topoview/viewer/\# (accessed on 26 February 2021).

53. Marsh, A. The Thermal Simulation Engine; Autodesk Inc.: San Rafael, USA, 2008.

54. GloVis U.G.V.V. United States Geological Survey. Available online: http:/ / glovis.usgs.gov/ (accessed on 26 February 2021).

55. Tsou, J.; Zhuang, J.; Li, Y.; Zhang, Y. Urban heat island assessment using the landsat 8 data: A case study in Shenzhen and Hong Kong. Urban Sci. 2017, 1, 10. [CrossRef]

56. Rajeshwari, A.; Mani, N.D. Estimation of land surface temperature of dindigul district using landsat 8 data. Int. J. Res. Eng. Technol. 2014, 3, 122-126. [CrossRef]

57. Hague, P.; Harris, P. Sampling and Statistics; Kogan Page: London, UK, 1993; p. 144. 
58. Hillier, B.; Penn, A.; Hanson, J.; Grajewski, T.; Xu, J. Natural movement: Or, configuration and attraction in urban pedestrian movement. Environ. Plan. B Plan. Des. 1993, 20, 29-66. [CrossRef]

59. Hillier, B.; Sahbaz, O. An evidence based approach to crime and urban design, or, can we have vitality, sustainability and security all at once? Bartlett Sch. Grad. Stud. Univ. Coll. Lond. 2008, 23, 1-28.

60. Öztürk Hacar, Ö.; Gülgen, F.; Bilgi, S.; K1lıç, B. Accessibility analysis of street networks using space syntax. In Proceedings of the 7th International Conference on Cartography \& GIS, Sozopol, Bulgaria, 18-23 June 2018.

61. Crawley, D.; Lawrie, L. Development of global Typical Meteorological Years (TMYx)(2019). Last Accessed 2020, $2,5$.

62. Mohamed, M. An approach to integrate the environmental impact assessment process in the early stages of design. In Proceedings of the The First International Engineering Conference Hosting Major International Events Innovation, Creativity and Impact Assessment, Housing \&Building National Research Center, Cairo, Egypt, 15-18 January 2013.

63. Mohamed, M.; Gado, T. Application of computer based environmental assessment and optimization tools: An approach for appropriating buildings. In Proceedings of the 3rd International Conference ArchCairo 2006, Appropriating Architecture taming Urbanism in the decades of transformation, Cairo, Egypt, 21-23 February 2006; pp. 592-604.

64. Nicol, J.F.; Humphreys, M.A. Adaptive thermal comfort and sustainable thermal standards for buildings. Energy Build. 2002, 34, 563-572. [CrossRef]

65. Pi Kappa Alpha. Makkah CAD Files; Pi Kappa Alpha: Memphis, TN, USA, 2021.

66. Hillier, B.H.J. The Social Logic of Space; Cambridge University Press: Cambridge, UK, 1984.

67. Hillier, B. Space is the Machine: A Configurational Theory of Architecture; Space Syntax: London, UK, 2007.

68. Salvati, A.; Monti, P.; Coch Roura, H.; Cecere, C. Climatic performance of urban textures: Analysis tools for a Mediterranean urban context. Energy Build. 2019, 185, 162-179. [CrossRef]

69. Evola, G.; Gagliano, A.; Fichera, A.; Marletta, L.; Martinico, F.; Nocera, F.; Pagano, A. UHI effects and strategies to improve outdoor thermal comfort in dense and old neighbourhoods. Energy Procedia 2017, 134, 692-701. [CrossRef]

70. Lemus-Canovas, M.; Martin-Vide, J.; Moreno-Garcia, M.C.; Lopez-Bustins, J.A. Estimating Barcelona's metropolitan daytime hot and cold poles using Landsat-8 Land Surface Temperature. Sci. Total Environ. 2020, 699, 134307. [CrossRef] [PubMed]

71. Equere, V.; Mirzaei, P.A.; Riffat, S.; Wang, Y. Integration of topological aspect of city terrains to predict the spatial distribution of urban heat island using GIS and ANN. Sustain. Cities Soc. 2021, 69, 102825. [CrossRef]

72. He, B.-J.; Ding, L.; Prasad, D. Relationships among local-scale urban morphology, urban ventilation, urban heat island and outdoor thermal comfort under sea breeze influence. Sustain. Cities Soc. 2020, 60, 102289. [CrossRef]

73. Mady Mohamed, A.A.; Noureddine, Z.; Soufiane, F. Predicting the limits of the oasis effect as a cooling phenomenon in hot deserts, An applied study on the Sahara oases. J. Arid. Environ. 2019, 24, 255-266.

74. Mohamed, M.; Soufiane, F.; Atef, A.; Salaheddine, D. Quantifying the effectiveness of mass proportions and the orientation for buildings on thermal performance in Tebessa, Algeria. IOP Conf. Ser. Earth Environ. Sci. 2019, 397, 012008. [CrossRef]

75. Shawesh, R.; Mohamed, M. Post occupancy evaluation of outdoor thermal comfort in hot arid zone. Int. J. Low Carbon Technol. 2021, 16, 50-60. [CrossRef]

76. Othman, A.; Abotalib, A.Z. Land subsidence triggered by groundwater withdrawal under hyper-arid conditions: Case study from Central Saudi Arabia. Environ. Earth Sci. 2019, 78, 243. [CrossRef]

77. Lazzarini, M.; Marpu, P.R.; Ghedira, H. Temperature-land cover interactions: The inversion of urban heat island phenomenon in desert city areas. Remote Sens. Environ. 2013, 130, 136-152. [CrossRef]

78. Kim, S.W.; Brown, R.D. Urban heat island (UHI) intensity and magnitude estimations: A systematic literature review. Sci. Total Environ. 2021, 779, 146389. [CrossRef]

79. Dewan, A.; Kiselev, G.; Botje, D.; Mahmud, G.I.; Bhuian, M.H.; Hassan, Q.K. Surface urban heat island intensity in five major cities of Bangladesh: Patterns, drivers and trends. Sustain. Cities Soc. 2021, 71, 102926. [CrossRef]

80. Khare, V.R.; Vajpai, A.; Gupta, D. A big picture of urban heat island mitigation strategies and recommendation for India. Urban Clim. 2021, 37, 100845. [CrossRef]

81. Liu, H.; Huang, B.; Zhan, Q.; Gao, S.; Li, R.; Fan, Z. The influence of urban form on surface urban heat island and its planning implications: Evidence from 1288 urban clusters in China. Sustain. Cities Soc. 2021, 102987. [CrossRef]

82. Mushtaha, E.; Shareef, S.; Alsyouf, I.; Mori, T.; Kayed, A.; Abdelrahim, M.; Albannay, S. A study of the impact of major Urban Heat Island factors in a hot climate courtyard: The case of the University of Sharjah, UAE. Sustain. Cities Soc. 2021, 69, 102844. [CrossRef] 